\title{
STUDY THE SATISFACTION LEVEL OF INTELLIGENT WHEELCHAIR WITH THE DISABLES - A STATISTICAL ANALYSIS
}

\section{KRISHNAVENI. K \& IDA MALARSELVI. R}

D G Government Arts College, Mayiladuthurai -609 001, Affiliated to Bharathidasan University Tamil Nadu, India

\begin{tabular}{|l} 
ABSTRACT \\
A sensorized device which has the facility of announcing the fire gas leake in indoor environment and also detect \\
the unauthorized person entry able to measure the distance of target to hit with load control which is designed \\
with the support of Multiple Sensors and decicated to wheelchair to prevent and secure the disable persons. After \\
the design feedback received from different age groups of both gender and their disability percentage and income \\
basis an analysis done how it is suitable to those people using SPSS package version 16.0 and the satistical study \\
explained in this paper and correlations findout the result is positive obtained from the stakeholders hence the \\
sensorized device is to be satisfy the need of the disables to promote their lifestyles and make them move alone \\
without attender support to get education employement oppurtunities. \\
KEYWORDS: Disables, IBM SPSS version 16.0, Satistical Analysis, Correlation
\end{tabular}

Received: Jun 08, 2020; Accepted: Jun 28, 2020; Published: Sep 22, 2020; Paper Id.: IJMPERDJUN20201381

\section{INTRODUCTION}

The SPSS programming software offers progressed factual investigation, an immense library of AI calculations, text examination, open source extensibility, combination with enormous information and consistent organization into applications.Its usability, adaptability and versatility make SPSS open to clients of all expertise levels. Also, it's reasonable for tasks all things considered and levels of unpredictability, and can assist association with finding new chances, improve proficiency and limit hazard. Inside the SPSS programming group of items, SPSS Statistics underpins a top- down, speculation testing way to deal with the information while SPSS Modeler uncovered examples and models covered up in information through a base up, generation approach.

SPSS Statistics, the world's driving measurable programming, is intended to take care of business and exploration issues through specially appointed investigation, speculation testing, geospatial examination and prescient examination. SPSS is short for Statistical Package for the Social Sciences, and it's utilized by different sorts of analysts for complex measurable information examination. The SPSS programming bundle was made for the administration and measurable investigation of sociology information. It was initially propelled in 1968 by SPSS Inc., and was later gained by IBM in 2009.

Formally named IBM SPSS Statistics, most clients despite everything allude to it as SPSS. As the world standard for sociology information investigation, SPSS is broadly desired due it is clear and English-like order language and amazingly exhaustive client manual. SPSS is utilized by economic scientists, wellbeing specialists, overview organizations, government elements, training analysts, advertising associations, information excavators, and a lot more for the handling and breaking down of review information. While Survey Gizmo (Example 
reference site) has ground-breaking worked in detailing highlights, with regards to top to bottom factual investigation analysts consider SPSS the top tier arrangement. Most top exploration offices use SPSS to break down review information and mine content information with the goal that they can take advantage of their examination ventures.

\section{MATERIAL \& METHODS}

\section{Data Analysis}

The Information is obtained through direct examination of various responders with various age class and inabilities. Those information have been dissected by utilizing factual programming (IBM SPSS ver.16.0)

Role of the statistical model using IBM SPSS version 16.0 for the direct investigation of multiple responders with different age class and disabilities

After the equipment has been designed, an investigation was finished with many handicapped people. Their sentiment was gathered with respect to the significance and execution of the gadget appropriate to their incapacity rate indicated by Government of Tamil Nadu. For this reason, disabled peoples who are in the accompanying region considered for a significant committment. Consequently, the rural region of Thalaisengadu, Sirkali, Thirukkadaiyur, Mamakudi, Manikkapangu, Eluppore, Akkur, Sembanarkovil, Thillaiyadi, Kodankudi and Nedumaruthur are covered for information assortment. After the information assortment, the gathered information is broke down through the product of IBM SPSS version16.0 and a positive relationship is got. Table 1 shows the details of disabled persons and their feedbacks about the proposed device.

Table 1: Details of disabled persons and their feedbacks

\begin{tabular}{|c|c|c|c|c|c|c|c|}
\hline 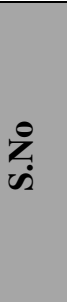 & 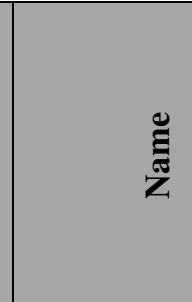 & $\underset{\alpha}{\stackrel{0}{*}}$ & 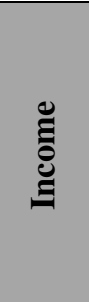 & 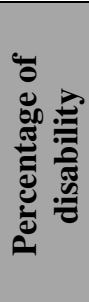 & 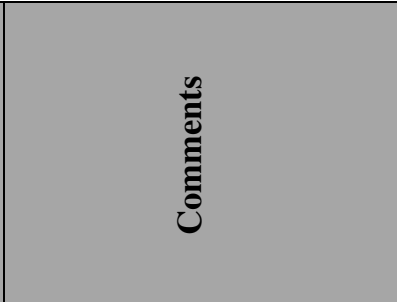 & 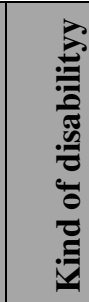 & 这 \\
\hline 1. & R.Deivanai & 33 & 2000 & 75 & Performance is Good & LD & Female \\
\hline 2. & Kalaiselvi & 40 & 7000 & 100 & Good instrument for disable & LD & Female \\
\hline 3. & M.Karikalan & 49 & 4000 & 100 & Useful and fantastic & VI & Male \\
\hline 4. & R.Jayanthi & 55 & 7000 & 45 & Useful & LD & Female \\
\hline 5. & Prabhakaran & 38 & 7500 & 60 & $\begin{array}{l}\text { Unauthorized entry } \\
\text { prevention is more useful } \\
\text { compare to others }\end{array}$ & LD & Male \\
\hline 6. & Muralidass & 48 & 5000 & 80 & No comments & LD & Male \\
\hline
\end{tabular}




\begin{tabular}{|c|c|c|c|c|c|c|c|}
\hline 7. & N.Rajendran & 62 & Nil & 80 & More useful and support & LD & Male \\
\hline 8. & Senthamilselvan & 44 & 8000 & 50 & $\begin{array}{l}\text { Related to disables the } \\
\text { device designed is good }\end{array}$ & LD & Male \\
\hline 9. & N.Kalidass & 33 & 7000 & 80 & More Useful & LD & Male \\
\hline 10. & M.Madhavan & 36 & 7000 & 100 & $\begin{array}{l}\text { It is more useful and } \\
\text { applicablefor VI }\end{array}$ & VI & Male \\
\hline 11. & Saravanan & 44 & 7000 & 80 & accident & LD & Male \\
\hline 12. & Kalaiarasi & 25 & 2000 & 80 & More satisfaction & LD & Female \\
\hline 13. & Jayakumarkeela & 48 & 5000 & 100 & Device is more useful & VI & Male \\
\hline 14. & Rajesh & 31 & 6500 & 80 & disables & LD & Male \\
\hline 15. & Jenittamari & 20 & Nil & 100 & $\begin{array}{l}\text { This device is more useful } \\
\text { during emergency for } \\
\text { disables }\end{array}$ & LD & Female \\
\hline 16. & Kalaivanan & 56 & 8000 & 65 & Useful for myself & LD & Female \\
\hline 17. & S.Narmadhadevi & 29 & Nil & 66 & Excellent & LD & male \\
\hline 18. & Kaliyarasi & 24 & 5000 & 80 & Excellent & LD & Female \\
\hline 19. & Rajapillai & 42 & 8000 & 75 & Device is more special & & Male \\
\hline 20. & Deepa & 18 & 6000 & 40 & $\begin{array}{l}\text { Device is most useful for } \\
\text { disables }\end{array}$ & LD & Female \\
\hline
\end{tabular}




\begin{tabular}{|c|c|c|c|c|c|c|c|}
\hline 21. & Usha & 36 & 7000 & 60 & $\begin{array}{l}\text { Device performance is } \\
\text { excellent }\end{array}$ & LD & Female \\
\hline 22. & Mohanraj & 30 & 6000 & 40 & $\begin{array}{l}\text { Device performance is most } \\
\text { excellent }\end{array}$ & LD & Male \\
\hline 23. & Selvaraj & 34 & 6500 & 60 & Applicable & $\mathrm{LD}$ & Male \\
\hline 24. & Chandra & 50 & 7000 & 50 & Good & LD & Female \\
\hline 25. & K.Manikandan & 39 & 15000 & 85 & Added more feature & $\mathrm{LD}$ & Male \\
\hline 26. & Manivasakan & 30 & 3000 & 40 & No comments & LD & Male \\
\hline 27. & B.Chandrahasan & 70 & Nil & 80 & $\begin{array}{l}\text { All sensors are most useful } \\
\text { so it is used for all } \\
\text { applications }\end{array}$ & LD & Male \\
\hline 28. & J.Dhanalakshmi & 40 & Nil & 50 & $\begin{array}{l}\text { All sensors are most useful } \\
\text { so it is used for all } \\
\text { applications }\end{array}$ & LD & Female \\
\hline 29. & Sridharan & 47 & 6000 & 70 & $\begin{array}{l}\text { All sensors are most useful } \\
\text { so it is used for all } \\
\text { applications }\end{array}$ & LD & Male \\
\hline 30. & S.Indira & 45 & Nil & 60 & $\begin{array}{l}\text { All sensors are most useful } \\
\text { so it is used for all } \\
\text { applications }\end{array}$ & LD & Female \\
\hline 31. & K.Cauveri & 35 & Nil & 90 & $\begin{array}{l}\text { Fire,Gas sensor and } \\
\text { unauthorized entry } \\
\text { prevention are more useful }\end{array}$ & Dumb & Female \\
\hline 32. & G.Gnanamani & 38 & Nil & 80 & $\begin{array}{l}\text { All sensors are most useful } \\
\text { so it is used for all } \\
\text { applications }\end{array}$ & Dumb & Male \\
\hline 33. & Bhuvaneswari & 34 & Nil & $\begin{array}{c}\text { Not } \\
\text { mentioned }\end{array}$ & $\begin{array}{l}\text { Unauthorized entry } \\
\text { prevention is more useful } \\
\text { compare to others }\end{array}$ & LD & Female \\
\hline 34. & G.Valliyammai & 60 & Nil & 50 & $\begin{array}{l}\text { All sensors are most useful } \\
\text { so it is used for all } \\
\text { applications }\end{array}$ & HD & Female \\
\hline
\end{tabular}




\begin{tabular}{|c|c|c|c|c|c|c|c|}
\hline 35. & R.Revathi & 38 & Nil & 50 & $\begin{array}{l}\text { All sensors are most useful } \\
\text { so it is used for all } \\
\text { applications }\end{array}$ & HD & Female \\
\hline 36. & B.Revathi & 40 & Nil & 100 & $\begin{array}{l}\text { All sensors are most useful } \\
\text { so it is used for all } \\
\text { applications }\end{array}$ & VI & Female \\
\hline 37. & N.Sundaramoorthi & 38 & Nil & 50 & $\begin{array}{l}\text { All sensors are most useful } \\
\text { so it is used for all } \\
\text { applications }\end{array}$ & HD & Male \\
\hline 38. & P.Chandra & 38 & Nil & 80 & $\begin{array}{l}\text { All sensors are most useful } \\
\text { so it is used for all } \\
\text { applications }\end{array}$ & LD & Female \\
\hline 39. & Abirami sundaram & 56 & 1500 & 80 & Good useful device & HD & Female \\
\hline 40. & Velmurugan & 37 & 4500 & 50 & $\begin{array}{l}\text { Excellent,Future generation } \\
\text { can use it more,Applicable to } \\
\text { live }\end{array}$ & LD & Male \\
\hline 41. & Rajesh & 28 & 10,000 & 70 & Most useful device & LD & Male \\
\hline 42. & Arun & 20 & 9000 & 60 & Most useful device & LD & Male \\
\hline 43. & T.Udhayakumar & 31 & 5000 & 100 & $\begin{array}{l}\text { Donate this device very } \\
\text { quick }\end{array}$ & VI & Male \\
\hline 44. & Kavitha & 43 & 3000 & 50 & No comments & LD & Female \\
\hline 45. & Kalaivani & 38 & Nil & 100 & $\begin{array}{l}\text { All sensors are most useful } \\
\text { so it is used for all } \\
\text { applications }\end{array}$ & HI & Female \\
\hline 46. & Murugan & 44 & Nil & 50 & $\begin{array}{l}\text { All sensors are most useful } \\
\text { so it is used for all } \\
\text { applications }\end{array}$ & LD & Male \\
\hline 47. & Mageswari & 40 & Nil & 40 & $\begin{array}{l}\text { All sensors are most useful } \\
\text { so it is used for all } \\
\text { applications }\end{array}$ & $\mathrm{HI}$ & Female \\
\hline 48. & Renganathan & 46 & Nil & 50 & $\begin{array}{l}\text { All sensors are most useful } \\
\text { so it is used for all } \\
\text { applications }\end{array}$ & LD & Male \\
\hline
\end{tabular}




\begin{tabular}{|c|c|c|c|c|c|c|c|}
\hline 49. & K.Chandra & 51 & Nil & 50 & $\begin{array}{l}\text { All sensors are most useful } \\
\text { so it is used for all } \\
\text { applications }\end{array}$ & LD & Female \\
\hline 50. & A.Anbarasan & 40 & 5000 & 45 & $\begin{array}{l}\text { All sensors are most useful } \\
\text { so it is used for all } \\
\text { applications }\end{array}$ & LD & Male \\
\hline 51. & M.Dhaksinamoorthy & 50 & Nil & 75 & $\begin{array}{l}\text { All sensors are most useful } \\
\text { so it is used for all } \\
\text { applications }\end{array}$ & VI & Male \\
\hline 52. & B.Kalaiselvi & 45 & Nil & 100 & $\begin{array}{l}\text { All sensors are most useful } \\
\text { so it is used for all } \\
\text { applications }\end{array}$ & LD & Female \\
\hline 53. & R.Saraswathi & 37 & 5000 & 70 & $\begin{array}{l}\text { All sensors are most useful } \\
\text { so it is used for all } \\
\text { applications }\end{array}$ & LD & Female \\
\hline 54. & G.Savithri & 37 & 5000 & 90 & $\begin{array}{l}\text { All sensors are most useful } \\
\text { so it is used for all } \\
\text { applications }\end{array}$ & VI & Female \\
\hline 55. & J.Vembu & 21 & Nil & 100 & $\begin{array}{l}\text { All sensors are most useful } \\
\text { so it is used for all } \\
\text { applications }\end{array}$ & LD & Female \\
\hline 56. & $\begin{array}{l}\text { R.Vasuki } \\
\text { Rethenaswamy }\end{array}$ & 49 & 5000 & 60 & $\begin{array}{l}\text { All sensors are most useful } \\
\text { so it is used for all } \\
\text { applications }\end{array}$ & LD & Female \\
\hline 57. & M.Rethinasamy & 64 & 6000 & 80 & $\begin{array}{l}\text { All sensors are most useful } \\
\text { so it is used for all } \\
\text { applications }\end{array}$ & $\mathrm{HI}$ & Male \\
\hline 58. & P.Shankar & 43 & 8000 & 50 & $\begin{array}{l}\text { All sensors are most useful } \\
\text { so it is used for all } \\
\text { applications }\end{array}$ & LD & Male \\
\hline 59. & M.Elangovan & 47 & 5000 & 50 & $\begin{array}{l}\text { All sensors are most useful } \\
\text { so it is used for all } \\
\text { applications }\end{array}$ & LD & Male \\
\hline 60. & A.Chellathurai & 56 & 5000 & 65 & $\begin{array}{l}\text { All sensors are most useful } \\
\text { so it is used for all } \\
\text { applications }\end{array}$ & LD & Male \\
\hline 61. & P.Kalyanasundaram & 52 & 6000 & 40 & $\begin{array}{l}\text { All sensors are most useful } \\
\text { so it is used for all } \\
\text { applications }\end{array}$ & LD & Male \\
\hline 62. & R.Shanthi & 35 & 5000 & 65 & $\begin{array}{l}\text { All sensors are most useful } \\
\text { so it is used for all } \\
\text { applications }\end{array}$ & LD & Female \\
\hline
\end{tabular}




\begin{tabular}{|c|c|c|c|c|c|c|c|}
\hline 63. & S.Jayanthi & 32 & 6000 & 65 & $\begin{array}{l}\text { All sensors are most useful } \\
\text { so it is used for all } \\
\text { applications }\end{array}$ & LD & Female \\
\hline 64. & S.Siranjeevi & 35 & 5000 & 50 & $\begin{array}{l}\text { All sensors are most useful } \\
\text { so it is used for all } \\
\text { applications }\end{array}$ & LD & Female \\
\hline 65. & P.Meena & 36 & 6000 & 65 & $\begin{array}{l}\text { All sensors are most useful } \\
\text { so it is used for all } \\
\text { applications }\end{array}$ & LD & Female \\
\hline 66. & V.Sudha & 36 & 7000 & 90 & $\begin{array}{l}\text { All sensors are most useful } \\
\text { so it is used for all } \\
\text { applications }\end{array}$ & LD & Female \\
\hline 67. & A.Preethiluis & 37 & 5000 & 80 & $\begin{array}{l}\text { All sensors are most useful } \\
\text { so it is used for all } \\
\text { applications }\end{array}$ & $\mathrm{HI}$ & Female \\
\hline 68. & R.Jayabal & 30 & 5000 & 85 & Device performance is good & $\mathrm{HI}$ & Male \\
\hline 69. & S.Varadharajan & 60 & 5000 & 70 & Device performance is good & $\mathrm{CP}$ & Male \\
\hline 70. & K.Sathiyakumar & 26 & 5000 & 75 & Device performance is good & MD & Male \\
\hline 71. & S.Kalyanasundaram & 40 & 6000 & 50 & Device performance is good & LD & Male \\
\hline 72. & G.Babu & 34 & 6000 & 100 & Device performance is good & LD & Male \\
\hline 73. & S.Hariharan & 26 & 5000 & 75 & Device performance is good & MR & Male \\
\hline 74. & V.Vaidhegi & 28 & Nil & 90 & Device performance is good & MR & Male \\
\hline 75. & K.Ilayaraja & 32 & Nil & 80 & Device performance is good & $\mathrm{LD}$ & Male \\
\hline 76. & A.Kanagasabai & 63 & Nil & 45 & Device performance is good & LD & Male \\
\hline
\end{tabular}




\begin{tabular}{|c|c|c|c|c|c|c|c|}
\hline 77. & C.EstharRani & 55 & Nil & 95 & Device performance is good & $\mathrm{HI}$ & Female \\
\hline 78. & S.Bhramma Rajan & 45 & Nil & 100 & Device performance is good & LD & Male \\
\hline 79. & S.Selvakumar & 35 & 6000 & 70 & Device performance is good & LD & Male \\
\hline 80. & K.Sundaramoorthi & 37 & 7000 & 50 & Device performance is good & LD & Male \\
\hline 81. & P.Neelamegam & 34 & 5000 & 80 & Device performance is good & $\mathrm{HI}$ & Male \\
\hline 82. & R.Rajendran & 30 & 4000 & 100 & $\begin{array}{l}\text { All sensors are most useful } \\
\text { so it is used for all } \\
\text { applications }\end{array}$ & VI & Male \\
\hline 83. & S.Susi & 10 & Nil & 100 & Device performance is good & LD \& MR & Female \\
\hline 84. & R.Abinaya & 12 & Nil & 80 & Device performance is good & MR & Female \\
\hline 85. & R.Atchaya & 11 & Nil & 80 & Device performance is good & MR & Female \\
\hline 86. & P.Rajasekar & 40 & 3000 & 100 & Device performance is good & MR & Male \\
\hline 87. & Nallathambi & 45 & 3000 & 80 & Device performance is good & Dumb & Male \\
\hline 88. & S.Vinoth & 35 & 3000 & 50 & Device performance is good & LD & Male \\
\hline 89. & M.Prakalanathan & 50 & 3000 & 50 & Device performance is good & Dumb & Male \\
\hline 90. & R.Amutha & 40 & 3000 & 60 & Device performance is good & Dumb & Female \\
\hline
\end{tabular}




\begin{tabular}{|c|c|c|c|c|c|c|c|}
\hline 91. & B.Dhanalakshmi & 30 & Nil & 50 & Device performance is good & LD & Female \\
\hline 92. & Iyyasamy & 60 & 6000 & 50 & Device performance is good & LD & Male \\
\hline 93. & R.Thirunavukkarasu & 45 & 3000 & 50 & Device performance is good & $\mathrm{HD}$ & Male \\
\hline 94. & K.Sekar & 60 & 3000 & 90 & $\begin{array}{l}\text { All sensors are most useful } \\
\text { so it is used for all } \\
\text { applications }\end{array}$ & Deaf & Male \\
\hline 95. & Kalimuthu & 35 & 3000 & 80 & Device performance is good & MR & Male \\
\hline 96. & G.Rajalakshmi & 50 & 7000 & 50 & Device performance is good & LD & Female \\
\hline 97. & M.Palanivel & 45 & 7000 & 50 & Device performance is good & LD & Male \\
\hline 98. & A.Aravindhan & 17 & Nil & 40 & Device performance is good & $\mathrm{HI}$ & Male \\
\hline 99. & S.Kumar & 40 & Nil & 90 & Device performance is good & MR & Male \\
\hline 100 & V.Jawahar & 35 & 6000 & 50 & Device performance is good & LD & Male \\
\hline 101 & T.Murugan & 40 & Nil & 90 & Device performance is good & MR & Male \\
\hline 102 & K.Seetha Lakshmi & 60 & Nil & 50 & Device performance is good & LD & Female \\
\hline 103 & J.Ganesamurthy & 30 & Nil & 90 & Device performance is good & MR & Male \\
\hline 104 & Munusamy & 75 & 3000 & 50 & $\begin{array}{l}\text { Device performance is good } \\
\text { Fire sensor performance is } \\
\text { more applicable }\end{array}$ & LD & Male \\
\hline
\end{tabular}




\begin{tabular}{|l|l|l|l|l|l|l|l|}
\hline 105 & Jaisankar & 48 & 1000 & 80 & $\begin{array}{l}\text { All sensors are most useful } \\
\text { so it is used for all } \\
\text { applications }\end{array}$ & CP & Male \\
\hline 106 & M.Popy & 30 & Nil & 80 & $\begin{array}{l}\text { Safety and security device all } \\
\text { sensor are good }\end{array}$ & MR & Female \\
\hline 107 & K.Ramalingam & 60 & 3000 & 50 & $\begin{array}{l}\text { All sensors are most useful } \\
\text { so it is used for all } \\
\text { applications,the ultrasonic } \\
\text { sensor is most useful }\end{array}$ & LD & Male \\
\hline 108 & A.Murugan & 40 & Nil & 90 & $\begin{array}{l}\text { All sensors are good } \\
\text { ultrasonic sensor is more } \\
\text { useful }\end{array}$ & Dumb & Male \\
\hline 109 & S.Arumugam & 49 & 5000 & 60 & $\begin{array}{l}\text { All sensors are good for bed } \\
\text { written patient the device is } \\
\text { more useful }\end{array}$ & LD & Male \\
\hline
\end{tabular}

- LD-Leg Impairment

- VI-Visual Impairment

- $\quad$ MR-Mental Retardation CP- Cerebral Palsy

- HI-Hearing Impairment

From the above information collection of various age gathering, salary, level of disability, nature of disability, Sex and criticism of the structured equipment after continuous exhibition of unit from their home the results are gone through the SPSS bundle rendition 16.0 and connection decided the relationships is sure having estimation of 0.01 and input of the people this planned equipment is acknowledged by the persons. Table 2 and Table 3 shows the simulation result for the given information in the SPSS bundle adaptation 16.0 and the output made remarks are recorded as it. Similarly the graphical representation in given in graph 1.

Table 2: Simulation result

\begin{tabular}{|c|c|}
\hline Output Created Comments & 01-Mar-2020 17:30:13 \\
\hline Input $\quad$ Data & \\
\hline & C: $\backslash$ Users $\backslash p c \backslash$ Documents $\backslash$ spss new.sav \\
\hline Active Dataset Filter & DataSet 1 \\
\hline Weight Split File & $<$ none $>$ \\
\hline N of Rows in Working Data File & enone> \\
\hline Syntax & none> \\
\hline & 109 \\
\hline & GRAPH \\
\hline & LINE(MULTIPLE)=COUNT BY \\
\hline & Income BY Costfeasibility. \\
\hline Resources Processor Time & 00:00:00.406 \\
\hline Elapsed Time & $00: 00: 00.484$ \\
\hline
\end{tabular}


SAVE OUTFILE='C:IUsers\pclDocumentslspss new.sav' /COMPRESSED.

>Warning \# 5334. Command name: SAVE

> The SAVE command has succeeded. However, due to contention for the specified

>file, the data have been saved to a file with a different name.

>Saved to C:IUsers\pclDocuments\spss new_1.sav. GRAPH

/LINE(MULTIPLE)=COUNT BY Income BY Cost feasibility.

Table 3 Simulation output

\begin{tabular}{|c|c|}
\hline Output Created & 01-Mar-2020 17:31:54 \\
\hline \multicolumn{2}{|l|}{ Comments } \\
\hline \multirow[t]{2}{*}{ Input Data } & C:IUsers\pclDocuments\spss \\
\hline & new_1.sav \\
\hline Active Dataset & DataSet1 \\
\hline Filter & $\langle$ none $>$ \\
\hline Weight & <none > \\
\hline Split File & <none> \\
\hline $\mathrm{N}$ of Rows in Working Data File & 109 \\
\hline \multirow[t]{3}{*}{ Syntax } & GRAPH \\
\hline & $/$ LINE(MULTIPLE)=COUNT BY \\
\hline & Income BY Costfeasibility. \\
\hline Processor Time & 00:00:00.250 \\
\hline Elapsed Time & 00:00:00.266 \\
\hline
\end{tabular}

[DataSet1] C:IUsers\pc\Documents\spss new_1.sav

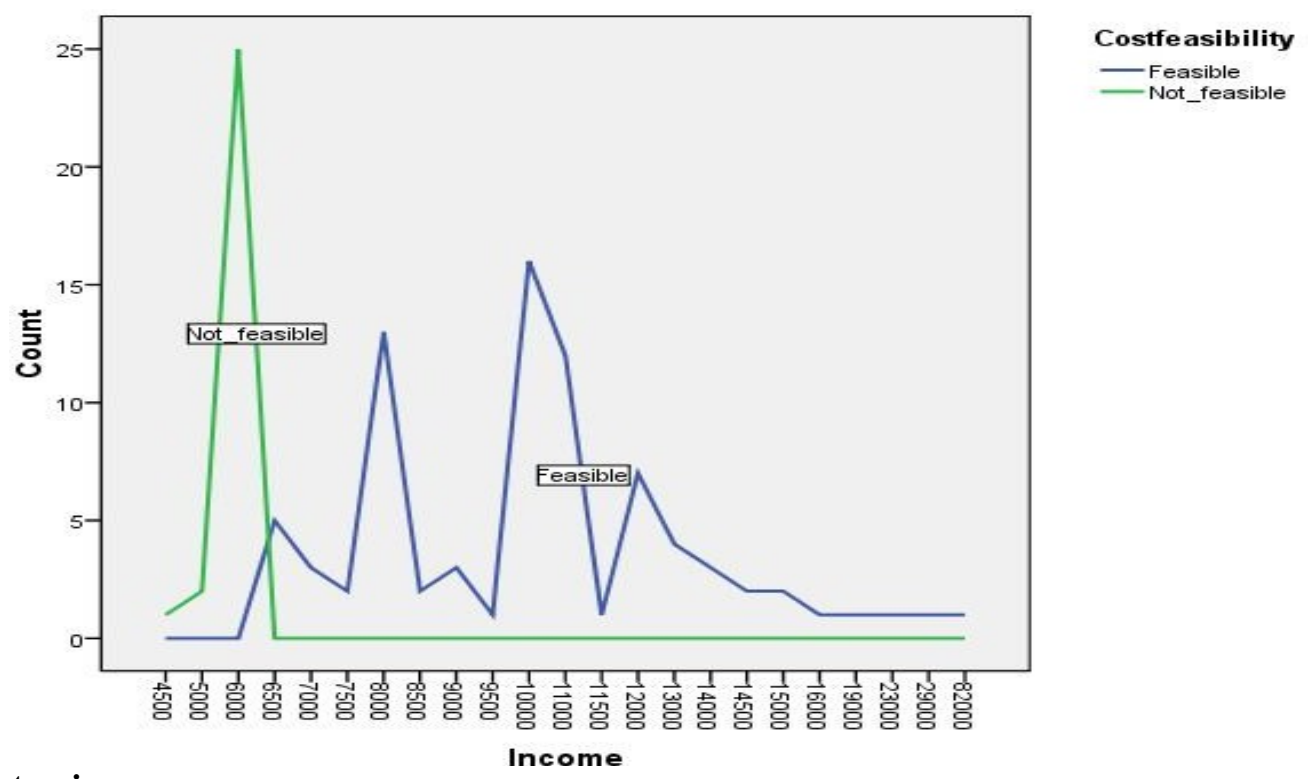

Graph 1: count vs income

SAVE OUTFILE='C:IUsers\pc\Documents\spss new_1.sav' /COMPRESSED. GRAPH1

$/$ LINE(MULTIPLE)=COUNT BY Age BY Comments.

On Depending the parameter of income basis and count value of the disabled person, the proposed model analyzed the feasibility of the person. On Referring table 1, the Table 3 shows the result. 
Table 4: Details of disabled person

\begin{tabular}{|l|l|}
\hline \multicolumn{1}{|c|}{ Output Created } & \multicolumn{1}{c|}{ 01-Mar-2020 18:18:32 } \\
\hline Comments & \multicolumn{1}{|c|}{} \\
\hline Input Data & C:IUserslpclDocuments\spss \\
\hline & new_1.sav \\
\hline Active Dataset & DataSet1 \\
\hline Filter & $<$ none $>$ \\
\hline Weight & <none $>$ \\
\hline Split File & <none $>$ \\
\hline N of Rows in Working Data File & 109 \\
\hline Syntax & GRAPH \\
\hline & /LINE(MULTIPLE)=COUNT BY \\
\hline & Age BY Comments. \\
\hline Resources Processor Time & 00:00:00.266 \\
\hline Elapsed Time & $00: 00: 00.265$ \\
\hline
\end{tabular}

[DataSet1] C:IUsers\pclDocuments\spss new_1.sav
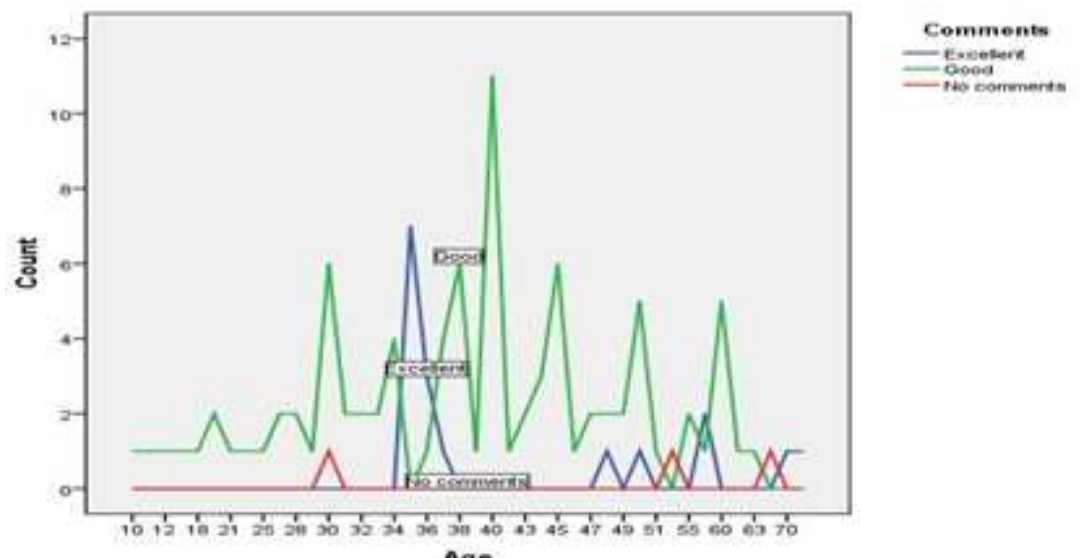

Graph 2: Age vs count

\section{RESULTS \& DISCUSSIONS}

From the Table 4 and graph 2, it clearly showed that the different age group of the persons with the count value and their satisfaction is drawn in this graph. Similarly the Table $5 \&$ Table 6 shows the correlation and income feasibility of the disabled person. 
Table 5: Correlation

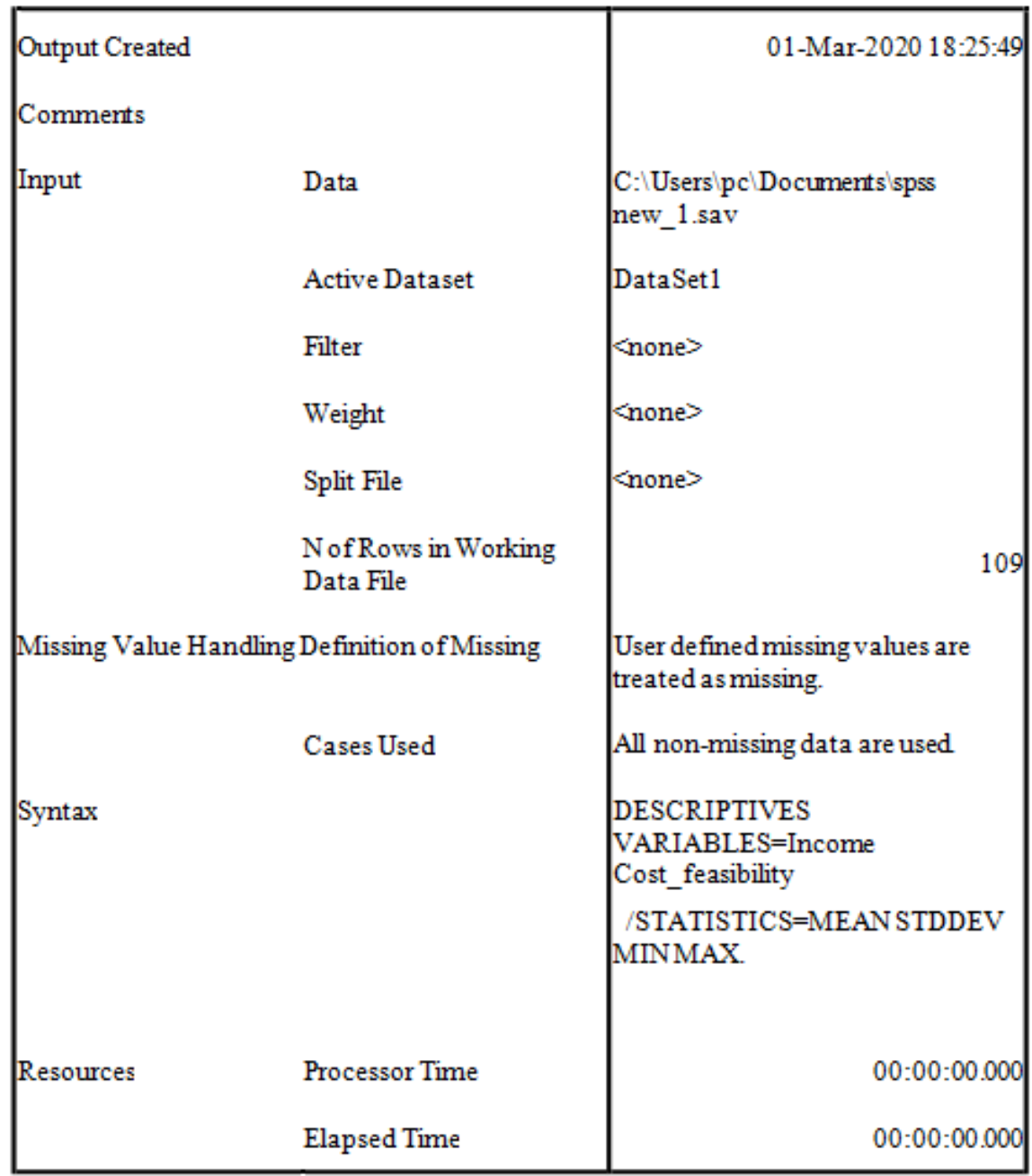

\section{CORRELATIONS}

/VARIABLES=Income Cost_feasibility

/PRINT=TWOTAIL NOSIG

/MISSING=PAIRWISE

Table 6: Correlations and feasibility

\begin{tabular}{|c|c|c|}
\hline Output Created & & \multirow{13}{*}{$\begin{array}{l}\text { 01-Mar-2020 18:27:10 } \\
\text { C:IUsers\pclDocumentslspss } \\
\text { new_1.sav } \\
\text { DataSet1 } \\
\text { <none> } \\
\text { <none> } \\
\text { <none> } \\
109 \\
\text { User-defined missing values are } \\
\text { treated as missing. } \\
\text { Statistics for each pair of variables } \\
\text { are based on all the cases with valid } \\
\text { data for that pair. }\end{array}$} \\
\hline \multirow{8}{*}{$\begin{array}{l}\text { Comments } \\
\text { Input }\end{array}$} & & \\
\hline & Data & \\
\hline & Active Dataset & \\
\hline & Filter & \\
\hline & Weight & \\
\hline & Split File & \\
\hline & $\mathrm{N}$ of Rows in Working & \\
\hline & Data File & \\
\hline Missing Value & Definition of Missing & \\
\hline \multirow[t]{2}{*}{ Handling } & & \\
\hline & Cases Used & \\
\hline Syntax & & \\
\hline
\end{tabular}




\begin{tabular}{|c|c|c|}
\hline Resources & Processor Time & $\begin{array}{l}\text { CORRELATIONS } \\
\text { /VARIABLES=Income } \\
\text { Cost_feasibility }\end{array}$ \\
\hline & Elapsed Time & $\begin{array}{l}\text { /PRINT=TWOTAIL NOSIG } \\
\text { /MISSING=PAIRWISE. } \\
\text { 00:00:00.047 } \\
\text { 00:00:00.063 }\end{array}$ \\
\hline
\end{tabular}

[DataSet1] C:IUsers\pclDocuments\spss new_1.sav

Then the Table 7 displays the correlation its value is 0.01 Hence it is positive. So the device is satisfied the people need with its multiple features.

Table 7: Correlation with value 0.001

\begin{tabular}{|c|c|c|c|}
\hline & & Income & Cost_feasibility \\
\hline \multirow[t]{3}{*}{ Income } & Pearson Correlation & 1 & $-.317^{* *}$ \\
\hline & Sig. (2-tailed) & & .001 \\
\hline & $\mathrm{N}$ & 109 & 109 \\
\hline \multirow[t]{3}{*}{ Cost_feasibility } & Pearson Correlation & $-.317^{* *}$ & 1 \\
\hline & Sig. (2-tailed) & .001 & \\
\hline & $\mathrm{N}$ & 109 & 109 \\
\hline
\end{tabular}

**. Correlation is significant at the 0.01 level (2-tailed).

\section{GET}

FILE='C: $\mid$ Users\pc\Documents\spss new_1.sav'. DATASET NAME DataSet1 WINDOW=FRONT.

SAVE OUTFILE='C:|Users\pc\Documents\spss new_1.sav' /COMPRESSED

>Warning \# 5334. Command name: SAVE

$>$ The SAVE command has succeeded. However, due to contention for the specified

$>$ file, the data have been saved to a file with a different name.

>Saved to C:IUsers\pc\Documents\spss new_2.sav. GET

FILE='C:IUsers \pc\Documents\spss new_1.sav'. DATASET NAME DataSet1 WINDOW=FRONT. GRAPH

/PIE=COUNT BY Disability percentage.

Finally, the Table 8 shows the disability percentage collected and similarly the graph 3 is represented for the percentage. These percentages are collected from various places of Nagapattinam districts which are shown in table 1 . As per the Tamilnadu Government disability card allotted to every person. 
Table 8: Disability percentage

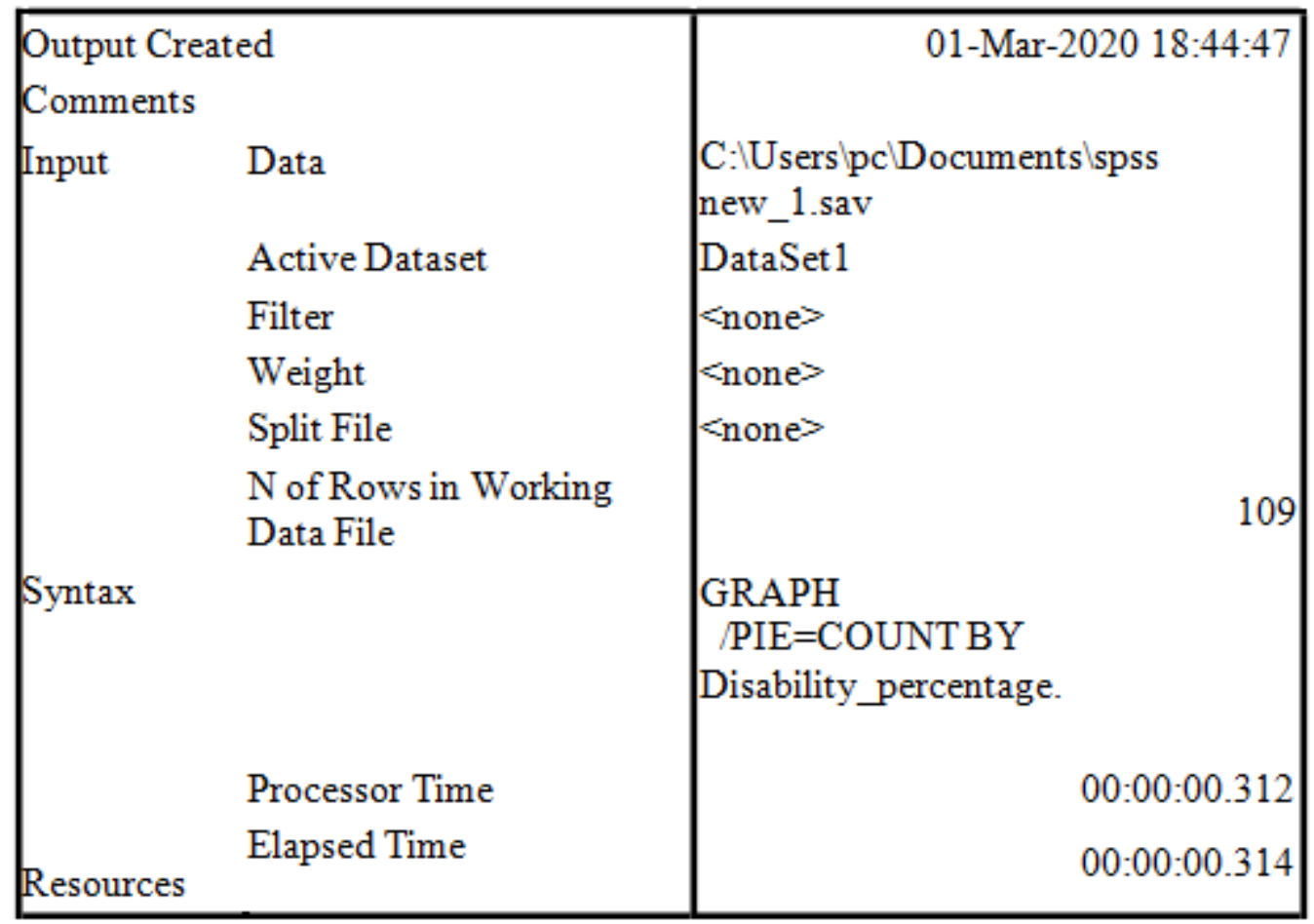

[DataSet1] C:IUsers\pc\Documents\spss new_1.sav

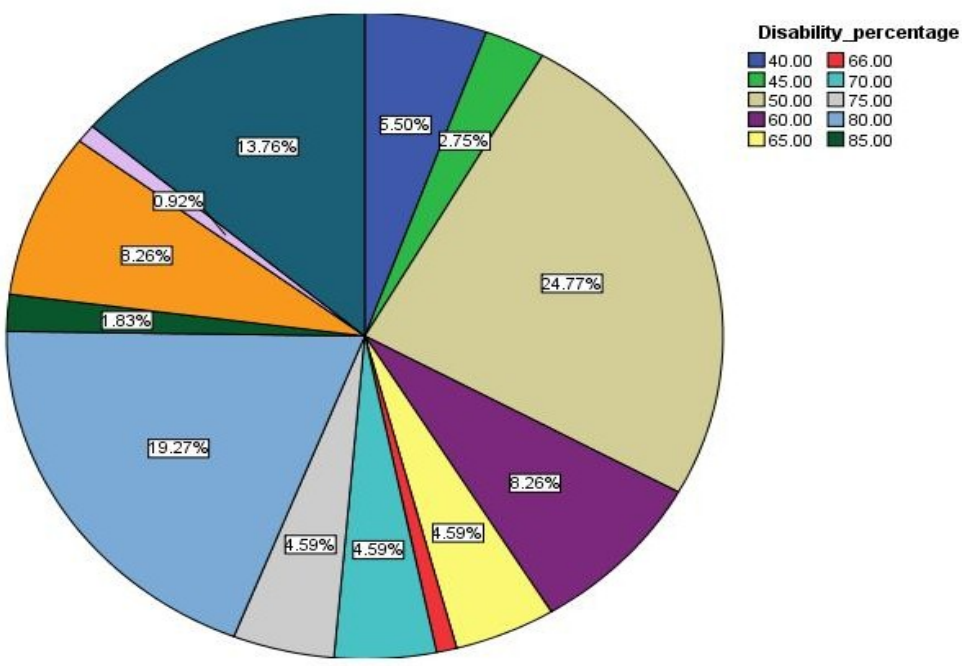

Graph 3: Graphical representation of Disability percentages

GRAPH

/PIE=COUNT BY Gender.

Then the Table 9 and Graph 4 represented the gender wise classification of persons recorded in table 1.

Table 9: gender classification in disabled

\begin{tabular}{|l|l|}
\hline \multicolumn{1}{|c|}{ Output Created } & \multicolumn{1}{|c|}{ 01-Mar-2020 18:55:51 } \\
\hline Comments & \multicolumn{1}{|c|}{ C:IUsers\pclDocuments\spss } \\
\hline Input Data & new_1.sav \\
\hline
\end{tabular}




\begin{tabular}{|l|l|}
\hline Active Dataset & DataSet1 \\
\hline Filter & $<$ none $>$ \\
\hline Weight & $<$ none $>$ \\
\hline Split File & $<$ none $>$ \\
\hline N of Rows in Working Data File & 109 \\
\hline Syntax & GRAPH \\
\hline & /PIE=COUNT BY Gender. \\
\hline Resources Processor Time & $00: 00: 00.234$ \\
\hline Elapsed Time & $00: 00: 00.218$ \\
\hline
\end{tabular}

[DataSet1] C:IUsers\pclDocuments\spss new_1.sav

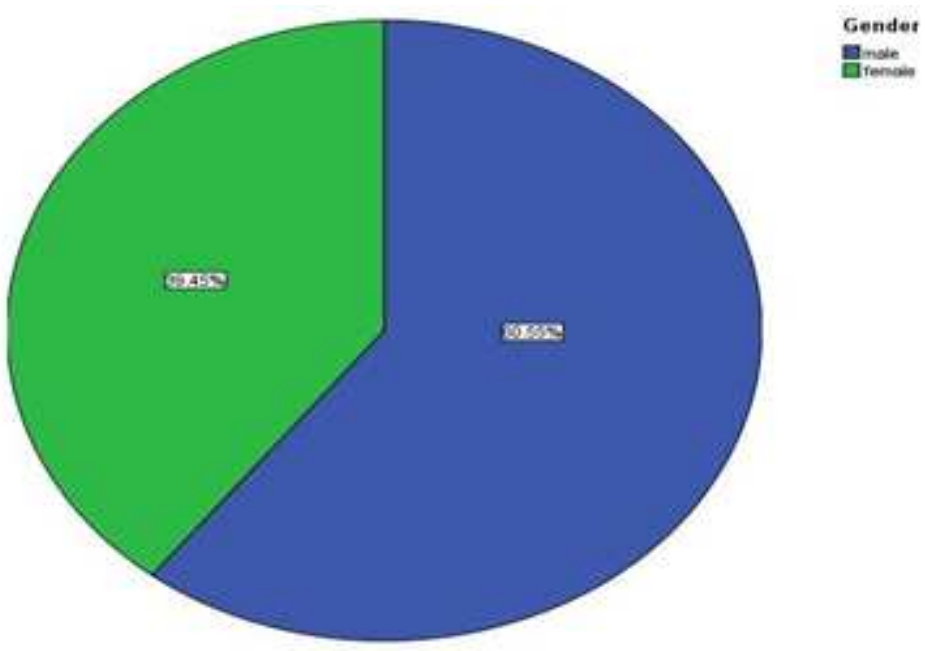

Graph 4: Graphical representations for gender classifications in disabled

GRAPH

VPIE=COUNT BY Disability.

Finally, the Table 10 and Graph 5 shows the various persons affected by disability reported in Table 1 that is Visually Impaired, Leg Disabled, Hand disabled, dumb, Deaf, Mentally retarted, Hearing Impaired and CP multiple disorders.

Table 10: Report based on different disabilities

\begin{tabular}{|l|l|}
\hline \multicolumn{1}{|c|}{ Output Created } & \multicolumn{1}{c|}{ 01-Mar-2020 18:59:15 } \\
\hline Comments & \multicolumn{1}{|c|}{ C:IUsers\pclDocuments\spss } \\
\hline Input Data & new_1.sav \\
\hline & DataSet1 \\
\hline Active Dataset & $<$ none $>$ \\
\hline Filter & <none> \\
\hline Weight & $<$ none $>$ \\
\hline Split File & 109 \\
\hline N of Rows in Working Data File & GRAPH \\
\hline Syntax & /PIE=COUNT BY Disability. \\
\hline & $00: 00: 00.203$ \\
\hline Resources Processor Time & $00: 00: 00.204$ \\
\hline Elapsed Time &
\end{tabular}

[DataSet1] C:IUsers\pclDocuments\spss new_1.sav 


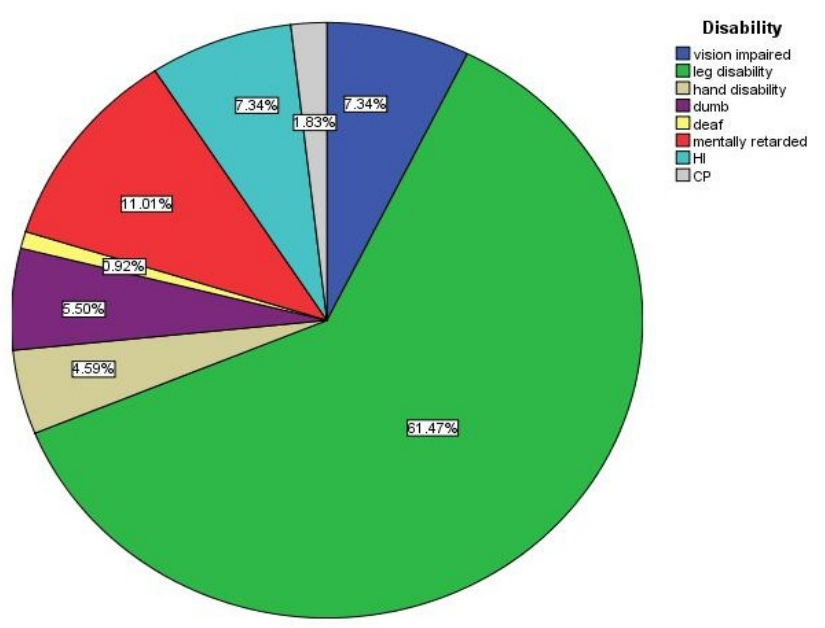

\section{Graph 5: Graph based on different disabilities}

\section{CONCLUSIONS}

In this research, the proposed model of smart sensor based gadget for Specially Abled Persons is planned having various kinds of six modules. The proposed is assembled in well manner and their working is checked with different exhibitions with the partners and income fulfillment level. These parameters are verified with various age groups and disability percentage is resolved in SPSS packages. This proposed work is acknowledged by the people and their fulfillment is at high level with the high correlation value

\section{REFERENCES}

1. community.ibm.com\

2. www.surveygizmo.com

3. www.uni-muenster.de > spss > spss_brief_guide_16.0.pdf 

